Журнал«Герстективита інновації наукиљ

(Серія «Гедагогіка», Серія «Гиихологія», Серія «Медицинв»

№(6) 2022

УДК 378.018.8:373.5.011.3-051:004]:37.091.279.7

https://doi.org/10.52058/2786-4952 -2022-1(6)-260-272

Медведсва Марія Олександрівна кандидат педагогічних наук, доцент, завідувач кафедри інформатики і інформаційно-комунікаційних технологій, Уманський державний педагогічний університет імені Павла Тичини, вул. Садова, 2, м. Умань, 30201, тел.: (04744) 3-45-82, https://orcid.org/ 0000-0001-9330-5185

Жмурко Олександр Іванович кандидат фізико-математичних наук наук, доцент, доцент кафедри інформатики i інформаційно-комунікаційних технологій, Уманський державний педагогічний університет імені Павла Тичини, вул. Садова, 2, м. Умань, 30201, тел.: (04744) 3-45-82, https://orcid.org/ 0000-0003-1362-0623

\title{
ПІДГОТОВКА МАЙБУТНІХ УЧИТЕЛІВ ІНФОРМАТИКИ ДО ВПРОВАДЖЕННЯ ФОРМУВАЛЬНОГО ОЦНЮВАННЯ
}

Анотація. Основним завданням організації сучасного освітнього процесу $\epsilon$ створення оптимальних умов для оволодіння здобувачами освіти ключовими та предметними компетентностями. Виконати поставлене завдання під силу лише творчому та відповідальному вчителю, який постійно самовдосконалюється, працює над собою та не лякається змін і викликів. Особливо це стосується вчителя інформатики у зв'язку із стрімкою зміною інформаційних технологій.

Відповідно до Концепції НУШ, майбутній випускник повинен володіти вміннями навчатися впродовж життя, критично мислити, ставити цілі та досягати їх, працювати в команді, спілкуватися в багатокультурному середовищі тощо. Для цього потрібно компетентні фахівці, зокрема які володіють навичками формувального оцінювання, що докорінно змінює як самі цілі оцінювання, так і підходи до оцінювання результатів навчання.

У статті розкриті різні підходи до формулювання визначення поняття «формувальне оцінювання», описано відмінності між діагностичним, формувальним, підсумковим та прогностичним оцінюваннями. Наведено приклади найпоширеніших технік формувального оцінювання: аналітичні запитання, рефлексивні техніки, однохвилинні есе, світлофор, уточнюючі питання, формувальні тести, міні-тести під час заняття, використання інтерактивних онлайн-сервісів, віртуальних інтерактивних дошок тощо. Запропоновано техніки формувального оцінювання (ментальні мапи та аркуші зворотного зв'язку), які доцільно використовувати на заняттях з інформатики. Описані найпоширеніші онлайн-ресурси, які використовують для створення ментальних мап: Mindomo, Mindmeister, Coggle. Наведені приклади запитань, 
які доцільно використовувати при складанні завдань для аркушу зворотного зв'язку на заняттях з інформатики за рівнями таксономії Б. Блума.

Експериментально підтверджено, що практика формувального оцінювання, зокрема 3 використанням таких технік, як аркуші зворотного зв'язку та ментальні мапи у закладі вищої освіти при роботі з майбутніми вчителями дає можливість ефективно оцінити здобувачів освіти на засадах компетентнісного підходу та продемонструвати їм досвід реалізації формувального оцінювання, що $є$ безперечно важливим для їх подальшої роботи у закладах загальної середньої освіти.

Ключові слова: формувальне оцінювання, освітній процес, нова українська школа, здобувачі освіти, майбутні учителі інформатики, ментальні мапи, аркуші зворотного зв'язку, таксономія Блума.

Medvedieva Mariia Oleksandrivna Candidate of Pedagogical Sciences, Associate Professor, Head of the Department of Informatics and Information and Communication Technologies, Pavlo Tychyna Uman State Pedagogical University, Sadova St., 2, Uman, 30201, tel.: (04744) 3-45-82, https://orcid.org/0000-0001-9330-5185

Zhmurko Oleksandr Ivanovych Candidate of Physical and Mathematical Sciences, Associate Professor, Associate Professor of the Department of Informatics and Information and Communication Technologies, Pavlo Tychyna Uman State Pedagogical University, Sadova St., 2, Uman, 30201, tel.: (04744) 3-45-82, https://orcid.org/0000-0003-1362-0623

\section{PREPARATION OF FUTURE INFORMATICS TEACHERS FOR IMPLEMENTATION OF FORMATIVE ASSESSMENT}

Abstract. The main task of the organization of the modern educational process is to create optimal conditions for the acquisition of key and subject competencies by students. Only a creative and responsible teacher, who is constantly improving himself, working on himself and is not afraid of changes and challenges, can fulfill the set task. This is especially true for computer science teachers due to the rapid change in information technology.

According to the NUS Concept, the future graduate must have the skills to learn throughout life, think critically, set goals and achieve them, work in a team, communicate in a multicultural environment and more. This requires competent professionals, in particular those who have the skills of formative assessment, which radically changes both the objectives of assessment and approaches to assessing learning outcomes.

The article reveals different approaches to the formulation of the definition of "formative assessment", describes the differences between diagnostic, formative, final and prognostic assessments. Examples of the most common formative 
assessment techniques are given: analytical questions, reflective techniques, oneminute essays, traffic lights, clarification questions, formative tests, mini-tests during the lesson, use of interactive online services, virtual interactive whiteboards, etc. Formative assessment techniques (mental maps and feedback sheets) are suggested for use in computer science classes. Describes the most common online resources used to create mental maps: Mindomo, Mindmeister, Coggle. Examples of questions that should be used when compiling tasks for the feedback sheet in computer science classes at the levels of taxonomy B. Bloom.

It is experimentally confirmed that the practice of formative assessment, in particular using techniques such as feedback sheets and mental maps in higher education institutions when working with future teachers allows to effectively assess students on the basis of competence approach and demonstrate experience in formative assessment. is undoubtedly important for their further work in general secondary education institutions.

Keywords: formative assessment, educational process, new Ukrainian school, students, future computer science teachers, mental maps, feedback sheets, Bloom's taxonomy.

Постановка проблеми. В Професійному стандарті зазначено, що однією 3 професійних компетентностей вчителя закладу загальної середньої освіти $\epsilon$ оцінювально-аналітична компетентність (ГЗ), яка включає: здатність здійснювати оцінювання результатів навчання здобувачів освіти (Г3.1), аналізувати результати навчання здобувачів освіти (Г3.2), забезпечувати самооцінювання та взаємооцінювання результатів навчання здобувачів освіти (Г3.3). Для реалізації даної компетентності вчитель має володіти певними знаннями, уміннями та навичками, зокрема, знати методики здійснення формувального, поточного, підсумкового оцінювання (Г3.1.33) та вміти застосовувати до різних видів оцінювання відповідну методику та шкалу (Г3.1.У2) [10].

Зокрема, у Концепції Нової української школи зазначено, що «Буде змінено підходи до оцінювання результатів навчання. Оцінки слугуватимуть для аналізу індивідуального прогресу і плануванню індивідуального темпу навчання, а не ранжуванню учнів». Такі підходи сприятимуть підготовці фахівців, які будуть володіти вміннями навчатися впродовж життя, критично мислити, ставити цілі та досягати їх, працювати в команді, спілкуватися в багатокультурному середовищі тощо [8]. Зараз ці зміни відбуваються у початковій загальній освіті. Наступний етап - базова середня освіта, що потребує компетентного фахівця, який буде здатний створити відповідні умови для реалізації поставлених завдань, зокрема реалізовувати формувальне оцінювання у відповідності до Концепції НУШ. Дієвим способом пояснити сутність формувального оцінювання є практика його використання при роботі зі студентами у закладі вищої освіти, зокрема у процесі вивчення інформатичних дисциплін та методики навчання інформатики. 
Аналіз останніх досліджень i публікацій. Проблема оцінювання навчальних досягнень висвітлена у працях багатьох науковців. Так, у наукових працях Н. Морзе, В. Вембер, О. Барна розкрито суть формувального оцінювання, описано технологію його впровадження на прикладі навчальнометодичних комплексів 3 інформатики для 2 та 5 класів, здійснено огляд Інтернет-ресурсів з питань організації процесу оцінювання [7]. Використання прийомів формувального оцінювання на уроках інформатики у початковій школі досліджували у своїх працях Н. Стрілецька та О. Смаглюк [11]. Науковці О. Щербак, Н. Софій, Б. Бович у своїх працях розглядають сучасні теоретичні підходи до практики оцінювання та наголошують, що яку б філософію оцінювання не обрав для себе викладач, результати оцінювання мають бути достовірні, надійні та автентичні [12].

O. Локшина формувальне оцінювання трактує як «інтерактивне оцінювання прогресу навчання учнів, що дає змогу вчителю визначати потреби учнів та відповідним чином адаптувати процес навчання» [4].

Відповідно до Державного стандарту базової середньої освіти, що починає діяти 31 вересня 2022 р. для учнів, які навчаються за програмами дванадцятирічної повної загальної середньої освіти: «Метою інформатичної освітньої галузі $\epsilon$ розвиток особистості учня, здатного використовувати цифрові інструменти і технології для розв'язання проблем, розвитку, творчого самовираження, забезпечення власного і суспільного добробуту, критично мислити, безпечно та відповідально діяти в інформаційному суспільстві» [9].

Компетентнісний підхід до організації освітнього процесу вимагає перегляду основних напрямів до оцінювання навчальних досягнень здобувачів освіти. На зміну перевірки, чого не знають та не вміють здобувачі освіти, приходять методи та форми, які акцентують увагу на тому, що вони знають і вміють.

Мета статті - дослідити особливості підготовки майбутніх учителів інформатики до впровадження формувального оцінювання, описати техніки формувального оцінювання, які будуть ефективними на заняттях 3 інформатики та впровадити їх в освітній процес педагогічного ЗВО.

Виклад основного матеріалу. Основним завданням організації сучасного освітнього процесу $\epsilon$ створення оптимальних умов для оволодіння здобувачами освіти ключовими та предметними компетентностями. Виконати поставлене завдання під силу лише творчому та відповідальному вчителю, який постійно самовдосконалюється, працює над собою та не лякається змін і викликів. Особливо це стосується вчителя інформатики у зв'язку із стрімкою зміною інформаційних технологій.

Концепція НУШ бере свій початок із кращих систем освіти країн ЄС. У різних країнах підходи до оцінювання різні. Зокрема у Фінляндії, існують такі різновиди оцінювання як: діагностичне, формувальне, підсумкове i прогностичне [2].

Діагностичне оцінювання полягає у визначенні рівня компетентностей здобувача освіти. Формою такого оцінювання на уроках інформатики може 
бути тест, виконання практичного завдання, бесіда тощо. За результатами діагностичного оцінювання учитель може планувати викладання, добираючи відповідні методи та засоби навчання.

Формувальне оцінювання грунтується на визначенні того, яка взаємодія між учителем та здобувачами освіти сприяє покращенню результатів здобувачів освіти та досягненню поставлених цілей навчання. Формами формувального оцінювання є самооцінювання, оцінювання з боку однолітків, обговорення результатів оцінювання між здобувачем освіти і вчителем, зустрічі з батьками і здобувачем освіти тощо.

Підсумкове оцінювання ставить на меті оцінити рівень компетентності здобувача освіти. Його проводять після вивчення змістового модуля та по завершенні навчального року.

Прогностичне оцінювання є попереджувальним. У його межах ставлять цілі на майбутне навчання, спільно із здобувачем освіти обговорюють, що і як вивчати в майбутньому та якої допомоги він потребує.

У межах запровадження компетентнісного підходу необхідно впроваджувати нову систему вимірювання й оцінювання результатів навчання. Якщо методики діагностичного (попередній зріз знань) та підсумкового оцінювання (тематичне оцінювання) вивчаються майбутніми вчителями у процесі навчання в ЗВО, то формувальне поки що недостатньо внесене у зміст методичних дисциплін. Тому набуття навичок формувального оцінювання під час професійної педагогічної підготовки є на часі.

Одним із найважливіших структурних компонентів освітнього процесу $є$ контрольно-регулювальний i оцінно-результативний, де під поняттям контролю розуміють виявлення, вимір і оцінку результатів навчальних досягнень здобувачів освіти. Основною функцією контролю є забезпечення зовнішнього та внутрішнього зворотного зв'язку. Оцінювання є складовою діагностики навчальних досягнень здобувачів освіти [6]. Зокрема О. Локшина вважає, що оцінювання виконує цілу низку функцій в освітньому процесі: контролювальну, навчальну, діагностико-коригувальну, стимулювальномотиваційну, розвивальну, виховну та функцію управління процесом навчання [3].

Під формувальним оцінюванням будемо розуміти процес пошуку та інтерпретації даних, які здобувачі освіти та вчителі використовують для визначення того як здобувачі освіти просунулися в опануванні навчального матеріалу, куди їм необхідно рухатися і як це зробити найкраще. Формувальне оцінювання відбувається під час освітнього процесу і $є$ його частиною. Його можна розглядати як поточне, діагностичне або «оцінювання для навчання».

Формувальне оцінювання - це оцінювання у процесі навчання, під час якого: аналізуються знання, вміння, навички, особистісні якості, поведінка, встановлюється обернений зв'язок успіхів та невдач здобувача освіти; направляють і мотивують на подальше навчання, а також планують цілі та шляхи їх досягнення. Отже, формувальне оцінювання зосереджене на 
порівнянні успіхів здобувача з його попередніми досягненнями, пропозиціях про подальшу діяльність, підтримці розвитку здобувача освіти. Інструментами формувального оцінювання $\epsilon$ ефективні способи роботи, що дозволяють вчителям сформувати навички необхідні для якісного та гнучкого оцінювання навчальних досягнень здобувачів освіти.

Формувальне оцінювання дозволяє: побудувати індивідуальну траєкторію розвитку здобувача освіти; оцінити або визначити досягнення здобувачів освіти на кожному з етапів освітнього процесу; вчасно виявляти проблеми й запобігати їх накопиченню; мотивувати здобувачів освіти до прагнення здобути максимально можливі результати; виховувати ціннісні якості особистості, бажання навчатися, відсутність побоювання помилитися, переконання у своїх можливостях і здібностях.

Із метою визначення рівня усвідомлення здобувачами, що навчаються за освітньо-професійною програмою «Середня освіта (Інформатика)» за освітнім ступенем «бакалавр» поняття формувального оцінювання та техніках його використання було проведено опитування у якому взяло участь 43 респонденти. Результати опитування показали, що лише 27,9\% здобувачів орієнтуються в поняттях та техніках впровадження формувального оцінювання. Натомість решта опитаних не володіють поняттєвим апаратом та прикладами застосування формувального оцінювання досягнень здобувачів освіти.

Під час освітнього процесу використовуються різні техніки формувального оцінювання: аналітичні запитання, рефлексивні техніки, однохвилинні есе, світлофор, уточнюючі питання, формувальні тести, мінітести під час заняття, використання інтерактивних онлайн-сервісів, віртуальних інтерактивних дошок тощо.

Однією з ефективних технік формувального оцінювання є ментальні мапи (карти пам’яті, інтелект-карти).

Ментальні мапи - це особливий спосіб систематизації знань за допомогою схем. Головною особливістю цього способу є те, що він одночасно спонукає працювати обидві півкулі головного мозку, завдяки чому людина може на 100 \% використовувати свій потенціал. Такі карти можна виконувати вручну на аркушах паперу A3 або A4, а також за допомогою спеціальних комп'ютерних програм.

Ментальні мапи потрібні: для представлення великої кількості інформації у стислій формі; для того, щоб добре розібратися у новій темі; для генерації ідей; під час самоосвітньої діяльності.

Основні принципи за якими діє ментальна мапа: ментальна мапа повинна активізувати пам'ять та сприйняття; забезпечити максимально зручне «читання», що зробить мислення більш свідомим; аналіз створеної карти дозволяє зрозуміти «будову» мислення, того хто їі створив.

Правила створення: центральний рисунок (ідея, завдання) повинен бути більшим за інші і розташовуватися по центру; при створенні потрібно 
використовувати більше ніж три кольори; потрібно змінювати шрифти в залежності від того на скільки ці слова важливі, щоб отримати відповідну ієрархію; для з'єднання рисунків (думок) потрібно використовувати стрілки.

Ментальні мапи, що створили здобувачі освіти можна використовувати як засоби навчання, наочність на узагальнюючих заняттях в інших класах або групах.

Найпоширеніші онлайн-ресурси, які використовують для створення ментальних мап: Mindomo, Mindmeister, Coggle [5].

Mindomo (https://www.mindomo.com/) - інструмент для створення ментальних мап, заснований на мережній роботі, з функціями, які характерні тільки найрозвиненішим інструментам для створення ментальних мап. Як мережевий додаток, Mindomo дає можливість перегляду програми на комп'ютері, який підключений до мережі Інтернет. Mindomo підтримує Windows, Mac i Linux. Сервіс має дві версії роботи: безкоштовну Basic i платну Premium. Втім, для освітніх потреб безкоштовного пакету цілком вистачає. Крім звичного розміщення мапи у вигляді посилання у вільній версії пакету можливий і iї експорт у вигляді картинки, або в формат RTF i PDF. Мова інтерфейсу: англійська. Працюючи над створенням ментальних мап, здобувачі освіти не тільки ще раз перечитують навчальну статтю, але й навчаються структурувати отриману інформацію, виділяти ключові слова в тексті і встановлювати між ними змістовні зв'язки.

Mindmeister (https://www.mindmeister.com/) - це онлайн-додаток для створення ментальних мап. Передбачає кілька варіантів абонентської плати, а також надає можливість безкоштовного використання програми. На безкоштовній основі можливо побудувати 3 ментальні мапи 3 обмеженими можливостями експорту. Додаток має зручний інтерфейс і весь необхідний набір функцій, що дозволяє зрозуміти всю простоту і зручність технології ментальних мап. Недоліком програми $є$ можливість повноцінного використання тільки при регулярній оплаті.

Coggle (https://coggle.it/) - це безкоштовний онлайн-додаток, що підтримує спільну роботу над проєктами. У цій програмі $є$ можливість створювати зручні та ефектні ментальні мапи. Інтерфейс програми простий, але в той же час має безліч функцій, які роблять процес створення ментальних мап неймовірно простим. Програма підтримує використання зображень, індивідуальні кольорові схеми і можливість перегляду історії документа. Зберігання історії змін дозволяє повернутися до попередніх версій створеної мапи. Ментальні мапи, створені в програмі Coggle, можуть експортуватися в форматі PNG або PDF.

Ще одна техніка яка $\epsilon$ ефективною при реалізації формувального оцінювання - аркуші зворотного зв'язку.

Аркуш зворотного зв’язку - це документ, який використовує вчитель для формування якісної та кількісної оцінки проміжних та підсумкових 
результатів діяльності здобувачів освіти щодо засвоєння певних результатів навчання. Аркуш зворотного зв'язку дозволяє здобувачу:

- ставити власні цілі в опануванні навчального матеріалу та планувати діяльність щодо їх досягнення;

- отримувати інформацію про результати своєї діяльності без остаточної оцінки, а значить, зберігати мотивацію на подальшу діяльність із засвоєння навчального матеріалу;

- отримувати коментарі вчителя, які дозволяють спланувати діяльність, щоб отримати результат вищого рівня; опанувати алгоритм оцінки власного просування.

Використання таких аркушів спрощують зворотний зв'язок у процесі навчання та забезпечують наступність в оцінці подібних освітніх результатів у рамках вивчення різних тем як однієї дисципліни, так і на матеріалі різних дисциплін. Аркуші зворотного зв'язку як інструмент формувального оцінювання допомагають здобувачу освіти замислитися про те, як можна поліпшити якість своєї роботи і прийняти усвідомлене рішення про продовження або припинення роботи з опанування того чи іншого результату навчання. При складанні аркушів зворотного зв'язку виділяють наступні етапи: рівні навчальних цілей за Блумом, предметні результати, завдання та вправи, самооцінка, оцінка та коментар вчителя.

При складанні завдань для аркушів зворотний зв'язок варто орієнтуватися на таксономію Б. Блума, що $\epsilon$ ефективним інструментом для аналізу впливу навчання в здобувачів освіти на розвиток здібностей до запам'ятовування, осмислення і вирішення завдань [1].

Б. Блум виділяє шість категорій цілей навчання: знання, розуміння, застосування, аналіз, синтез, оцінка. Знання - це перша категорія цілей навчання, оскільки запам'ятовування є лише частиною складніших процесів співвіднесення, оцінки, реорганізації, у яких будуються вищі категорії навчальних цілей. Розуміння як категорія таксономії навчальних цілей відображається, на думку Б. Блума, у трьох типах поведінки: трансляції (перехід від конкретного до абстрактного, використання інших термінів, символів, переклад іншою мовою, переказ своїми словами), інтерпретації (реорганізація ідей у свідомості людини), виділення значних ідей, їх внутрішніх зв'язків, узагальнення, пояснення, короткий виклад), перенесення знань (оцінка та передбачення, засновані на розумінні напрямів, тенденцій, правил). Якщо оволодіння знаннями лише на рівні розуміння забезпечує використання здобувачами абстрактних понять, правил, принципів на цю тему, то засвоєння навчального матеріалу на рівні застосування передбачає, що він правильно застосує ці знання у ситуації, відмінній від тієї, у якій здобувач їх отримав. Якщо розуміння, на думку Б. Блума, орієнтує на «схоплювання» навчального матеріалу та занурення в нього, застосування на встановлені зв'язків даного матеріалу з відповідними узагальненнями та принципами, то аналіз спрямований на виділення окремих частин матеріалу, визначення їх 
взаємозв’язків та принципів організації, визначення припущень, висновків, концепцій, яких автор тексту дотримується, хоча не висловлює явно.

Категорія синтезу позначає вміння комбінувати елементи так, щоб отримати ціле, що має новизну, збираючи матеріал із різних джерел разом так, щоб отримана модель або структура була зрозумілішою, ніж вихідний матеріал. Розуміння, застосування знань та аналіз матеріалу $є$ необхідною умовою розв'язання задач синтезу, але вони не вимагають оригінальності, унікальності рішення. Оцінка як категорія таксономії позначає вміння оцінювати значення того чи іншого матеріалу (ствердження, художнього твору, дослідницьких даних), грунтується на чітких критеріях, на адекватному розумінні та аналізі явищ, що принципово відрізняє ії від суб'єктивних думок.

При застосуванні аркушів зворотного зв'язку всі прогнозовані результати, заплановані вчителем, дають позитивну динаміку і стабільні результати.

При складанні завдань для аркушу зворотного зв’язку на заняттях 3 інформатики можна скористатися таблицею 1.

Таблиия 1

Запитання за рівнями таксономії Б. Блума

\begin{tabular}{|c|c|c|}
\hline $\begin{array}{l}\text { Пізнавальний } \\
\text { процес }\end{array}$ & $\begin{array}{r}\text { Дісслова для } \\
\text { розробки завдань }\end{array}$ & Приклади завдань \\
\hline \multicolumn{3}{|c|}{ Знання (пам'ятати - отримувати інформацію з пам'яті) } \\
\hline Відтворення & $\begin{array}{l}\text { - назвіть; } \\
\text { - повторіть; } \\
\text { - напишіть } \\
\text { формулу...; } \\
\text { - перерахуйте...; } \\
\text { - в якому році...; } \\
\text { - відтворіть... }\end{array}$ & $\begin{array}{l}\text { - Відповісти на будь- } \\
\text { яке питання } \\
\text { альтернативного або } \\
\text { множинного вибору. } \\
\text { - Назвіть прізвища } \\
\text { вчених. }\end{array}$ \\
\hline $\begin{array}{l}\text { Пригадування, } \\
\text { впізнання }\end{array}$ & $\begin{array}{l}\text { - інсценуйте; } \\
\text { - де відбувалося... } \\
\text { - згадайте, } \\
\text { - оберіть, } \\
\text { - констатуйте, } \\
\text { - надайте, } \\
\text { - добудьте, } \\
\text { - виміряйте, } \\
\text { - підкресліть.... }\end{array}$ & $\begin{array}{l}\text { - Згадайте формулу. } \\
\text { - Знайдіть предмет, } \\
\text { що нагадує материнську } \\
\text { плату. }\end{array}$ \\
\hline \multicolumn{3}{|c|}{ Розуміння (розуміти - виявляти сутність) } \\
\hline Інтерпретація & $\begin{array}{l}\text { - закінчіть фразу; } \\
\text { - що ви дізналися; } \\
\text { - поясніть; } \\
\text { - виконайте } \\
\text { аналогією; } \\
\text { - перетворіть; } \\
\text { - поясніть } \\
\text { взаємозв'язок. }\end{array}$ & $\begin{array}{l}\text { - Подайте задачу у } \\
\text { виді алгебраїчного } \\
\text { рівняння. } \\
\text { - Намалюйте процес } \\
\text { передачі даних. }\end{array}$ \\
\hline
\end{tabular}




\begin{tabular}{|c|c|c|}
\hline $\begin{array}{c}\text { Наведення } \\
\text { прикладів }\end{array}$ & $\begin{array}{l}\text { - уточніть, } \\
\text { - співставте, } \\
\text { - перетворіть, } \\
\text { - проведіть } \\
\text { відмінності, } \\
\text { - проілюструйте, } \\
\text { - перекладіть на } \\
\text { іншу мову... } \\
\end{array}$ & $\begin{array}{c}\text { - Зобразіть діаграму. } \\
\text { - Назвіть декілька } \\
\text { мережевих протоколів. }\end{array}$ \\
\hline $\begin{array}{l}\text { Класифікація } \\
\text { Порівняння }\end{array}$ & $\begin{array}{l}\text { - класифікуйте, } \\
\text { - виявите } \\
\text { відмінності, } \\
\text { - розпізнайте, } \\
\text { - обговоріть, } \\
\text { - вкажіть... }\end{array}$ & $\begin{array}{l}\text { - Назвіть парні i } \\
\text { непарні числа. } \\
\text { - Виявіть відмінність } \\
\text { між технологіями Веб } 1.0 \\
\text { і Веб 2.0. }\end{array}$ \\
\hline $\begin{array}{l}\text { Пояснення } \\
\text { Умовивід }\end{array}$ & $\begin{array}{l}\text { - інтерпретуйте, } \\
\text { - систематизуйте, } \\
\text { - викладіть своїми } \\
\text { словами, } \\
\text { - спрогнозуйте } \\
\text { - розпізнайте, } \\
\text { - опишіть, } \\
\text { - переформулюйте, } \\
\text { - зробіть } \\
\text { (критичний) огляд... }\end{array}$ & 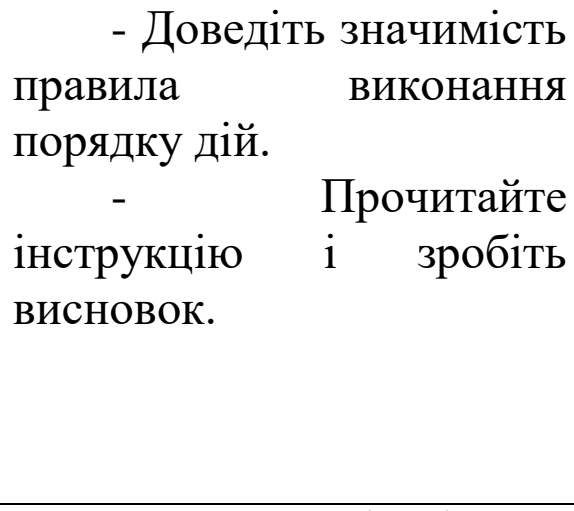 \\
\hline \multicolumn{3}{|c|}{$\begin{array}{l}\text { Застосування (Застосовувати - використовувати на практиці в інших } \\
\text { ситуаціях) }\end{array}$} \\
\hline Виконання & \begin{tabular}{|l} 
- перевірте \\
припущення; \\
- доведіть, що...; \\
- висловіть думку \\
про ...; \\
- висловіть гіпотезу; \\
- поясніть мету \\
застосування; \\
\end{tabular} & $\begin{array}{l}\text { - Додайте у стовпчик } \\
\text { двозначні числа. } \\
\text { - } \\
\text { завдання. }\end{array}$ \\
\hline Застс & $\begin{array}{l}\text { - продемонструйте, } \\
\text { - змініть, } \\
\text { - підготуйте, } \\
\text { - складіть, } \\
\text { - підтвердить.... }\end{array}$ & $\begin{array}{c}\text { - } \\
\text { експеримент. } \\
\text { - Складіть задачу. }\end{array}$ \\
\hline \multicolumn{3}{|c|}{$\begin{array}{l}\text { Аналіз (аналізувати - вичленяти } 3 \text { поняття частини та описувати як } \\
\text { частини співвідносяться } 3 \text { цілим) }\end{array}$} \\
\hline Диференціація & $\begin{array}{l}\text { - що є наслідком; } \\
\text { - порівняйте; } \\
\text { - проаналізуйте } \\
\text { причини; } \\
\text { - виведіть } \\
\text { формулу... }\end{array}$ & $\begin{array}{l}\text { - Порівняйте і зробіть } \\
\text { висновок. } \\
\quad \text { - Проаналізуйте } \\
\text { тенденції } \\
\text { вебтехнологій і розвитку } \\
\text { висновок. }\end{array}$ \\
\hline
\end{tabular}


Журнал«Герспективита іновації науки

(Серія «Гедагогіка», Серія «ГЕихологія», Серія «Медициғ»

№1(6) 2022

\begin{tabular}{|c|c|c|}
\hline Організація & $\begin{array}{l}- \\
\text { схематично, } \\
\text { - робрлазіньтье, } \\
\text { співставте та виділіть, } \\
\text { - проведіть } \\
\text { експеримент, } \\
\text { - перевірте гіпотезу, } \\
\text { - задайте питання } \\
\text {... }\end{array}$ & 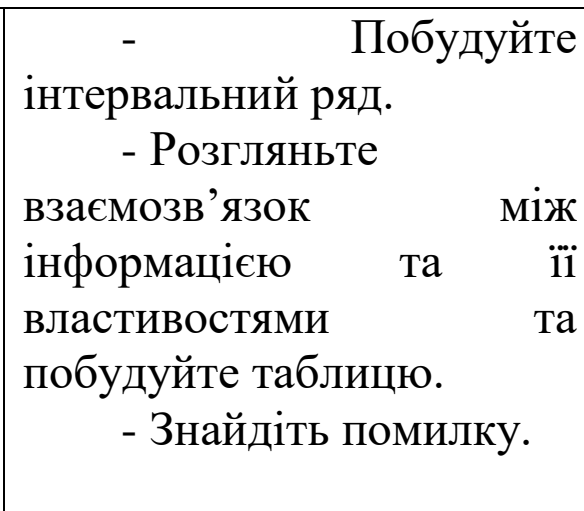 \\
\hline \multicolumn{3}{|c|}{ Синтез (Створити нове - об’єднати елементи у ціле) } \\
\hline Генерація & $\begin{array}{l}\text { - складіть із } \\
\text { елементів; } \\
\text { - систематизуйте; } \\
\text { - напишіть твір; } \\
\text { - запропонуйте план } \\
\text { експерименту; } \\
\text { - знайдіть } \\
\text { альтернативу; } \\
\text { - запропонуйте } \\
\text { алгоритм; } \\
\text { - які } \\
\text { пояснення... можливі }\end{array}$ & $\begin{array}{l}\text { - Запропонуйте } \\
\text { шляхи } \\
\text { проблеми. } \\
\text { - Запрошення } \\
\text { альтернативу. }\end{array}$ \\
\hline Планування & $\begin{array}{l}\text { - аргументуйте, } \\
\text { - систематизуйте, } \\
\text { - реконструюйте, } \\
\text { - запропонуйте, } \\
\text { - винайдіть .... }\end{array}$ & $\begin{array}{l}\text { - Розробіть план } \\
\text { дослідження. } \\
\text { - Складіть план для } \\
\text { розробки мультимедійної } \\
\text { презентації. } \\
\text { - Створіть кластер. }\end{array}$ \\
\hline \multicolumn{3}{|c|}{ Оцінка (Створити судження, які грунтуються на критеріях та еталонах) } \\
\hline Перевірка & $\begin{array}{l}\text { - аргументуйте } \\
\text { - прийміть рішення, } \\
\text { - складіть думку, } \\
\text { - рекомендуйте, } \\
\text { - вирішіть проблему }\end{array}$ & $\begin{array}{l}\text { - Проаналізуйте план } \\
\text { експерименту і дайте } \\
\text { оцінку. } \\
\quad \text { - Оцініть } \\
\text { критеріями } \\
\text { аргументованість виступу } \\
\text { групи. }\end{array}$ \\
\hline Критичність & $\begin{array}{l}\text { - зробіть оцінку, } \\
\text { - спрогнозуйте, } \\
\text { - оцініть, } \\
\text { - розробіть } \\
\text { оберіть критерії, } \\
\text { - захистіть точку } \\
\text { зору... }\end{array}$ & $\begin{array}{l}\text { - Чи відповідає ваш } \\
\text { спосіб вирішення задачі } \\
\text { еталону. } \\
\text { - Розробіть критерії } \\
\text { оцінки та оцініть проєкт. }\end{array}$ \\
\hline
\end{tabular}


3 метою визначення ефективності впровадження технік формувального оцінювання в освітній процес здобувачам, що навчаються за освітньопрофесійною програмою «Середня освіта (Інформатика)» за освітнім ступенем «бакалавр» було проведено контрольне діагностування. Результати опитування показали, що $83,7 \%$ респонденти не лише оволоділи техніками формувального оцінювання на практиці, а й покращили власні результати навчання.

Висновки. Таким чином, практика формувального оцінювання, зокрема 3 використанням таких технік, як аркуші зворотного зв'язку та ментальні мапи у закладі вищої освіти при роботі із майбутніми вчителями дає можливість ефективно оцінити здобувачів на засадах компетентнісного підходу та продемонструвати їм досвід реалізації формувального оцінювання, що є безперечно важливим для їх подальшої роботи у закладах загальної середньої освіти.

\section{Jimepamypa:}

1. Bloom B.S. Taxonomy of educational objectives: The classification of educational goals. New York : Longman, 1984. $207 \mathrm{p}$.

2. Діагностичне, формувальне, підсумкове - які види оцінювання у фінських школах. НУШ. URL: https://nus.org.ua/articles/otsinyuvannya-tse-navychka-i-zavzhdy-dialogfinskyj-dosvid/ (дата звернення: 28.12.2021).

3. Локшина О. І. Контроль та оцінка успішності учнів у школах Західної Європи. Київ : КМІУВ ім. Б. Грінченка, 2002. 52 с.

4. Локшина О. Інновації в оцінюванні навчальних досягнень учнів у шкільній освіті країн Європейського союзу. Порівняльно-педагогічні студії. 2009. № 2. С. 107-113.

5. Медведєва М.О., Жмурко О.І., Криворучко I.I., Ковтанюк М.С. Організація продуктивної взаємодії між учасниками освітнього процесу в умовах дистанційного навчання: аналіз сучасних додатків. Науковий часопис. 2021. № 80, т. 1. С. 39-45. http://chasopys.ps.npu.kiev.ua /archive/80/part_2/10.pdf

6. Мойсеюк Н. Є. Педагогіка : навчальний посібник. 5-те вид., доп. і перероб. Київ : Б.в., 2007. 655 с.

7. Морзе Н.В., Барна О.В., Вембер В.П. Формувальне оцінювання: від теорії до практики. Інформатика та інформаційні технології в навчальних закладах. 2013. №6. С. 4557. URL: http://elibrary.kubg.edu.ua/id/eprint/6327/1/MorzeNBarnaOVemberVIITNZ62013IS.pdf

8. Нова українська школа : Концепція від 27.10.2016 p. URL: https://mon.gov.ua/storage/app/media/zagalna\%20serednya/nova-ukrainska-shkolacompressed.pdf (дата звернення: 01.01.2022).

9. Про деякі питання державних стандартів повної загальної середньої освіти : Постанова Каб. Міністрів України від 30.09 .2020 p. № 898 . URL: https://www.kmu.gov.ua/npas/pro-deyaki-pitannya-derzhavnih-standartiv-povnoyi-zagalnoyiserednoyi-osviti-i300920-898 (дата звернення: 01.01.2022).

10. Про затвердження професійного стандарту за професіями «Вчитель початкових класів закладу загальної середньої освіти», «Вчитель закладу загальної середньої освіти», «Вчитель 3 початкової освіти (з дипломом молодшого спеціаліста)» : Наказ від 23.12.2020 p. № 2736-20. URL: https://zakon.rada.gov.ua/rada/show/v2736915-20\#n10 (дата звернення: 02.01.2022).

11. Стрілецька Н. М., Смаглюк О. С. Використання прийомів (технік) формувального оцінювання на уроках інформатики у початковій школі. Молодий вчений. 2020. №6 (82). C. 355-363. URL: http://molodyvcheny.in.ua/files/journal/2020/6/71.pdf 
12. Щербак О. І., Софій Н. З., Бович Б. Ю. Теорія і практика оцінювання навчальних досягнень: Навчально-методичний посібник / За наук. ред. О. І. Щербак. Івано-Франківськ, «Лілея-НВ», 2014. 136 с.

\section{References:}

1. Bloom, B. S. (1984). Taxonomy of educational objectives: The classification of educational goals. Longman.

2. Diahnostychne, formuvalne, pidsumkove - yaki vydy otsiniuvannia u finskykh shkolakh. [Diagnostic, formative, final - what types of assessment in Finnish schools]. (n.d.). Retrieved from https://nus.org.ua/articles/otsinyuvannya-tse-navychka-i-zavzhdy-dialog-finskyj-dosvid/ [in Ukrainian].

3. Lokshyna O. I. (2002). Kontrol' ta otsinka uspishnosti uchniv u shkolakh Zakhidnoyi Yevropy [Monitoring and evaluating student performance in Western European schools]. Kyiv: KMIUV im. B. Hrinchenka [in Ukrainian].

4. Lokshyna O. I. (2009). Innovatsii v otsiniuvanni navchalnykh dosiahnen uchniv u shkilnii osviti krain Yevropeiskoho Soiuzu [Innovations in the assessment of students' academic achievements in school education in the European Union]. Porivnialno-pedahohichni studii Comparative and pedagogical studies, 2, 107-114 [in Ukrainian].

5. Medvedieva, M. O., \& Zhmurko, O. I., \& Kryvoruchko, I. I., \& Kovtaniuk, M. S. (2021). Orhanizatsiia produktyvnoi vzaiemodii mizh uchasnykamy osvitnoho protsesu v umovakh dystantsiinoho navchannia: analiz suchasnykh dodatkiv [Organization of productive interaction between participants of the educational process in the conditions of distance learning: analysis of modern appendices]. Naukovyi chasopys - Scientific journal, 80, 39-45 [in Ukrainian].

6. Moiseiuk, N. Ye. (2007). Pedahohika [Pedagogy]. Kyiv: B.v. [in Ukrainian].

7. Morze, N. V., \& Barna, O. V., \& Vember, V. P. (2013). Formuvalne otsiniuvannia: vid teorii do praktyky [Formative assessment: from theory to practice]. Informatyka ta informatsiini tekhnolohii $v$ navchalnykh zakladakh [Informatics and information technologies in educational institutions], 6, 45-57 [in Ukrainian].

8. Nova ukrainska shkola : Kontseptsiia vid 27.10.2016 r. [New Ukrainian school: Concept from 27.10.2016]. (2016). (n.d.). mon.gov.ua. Retrieved from https://mon.gov.ua/storage/app/media/ zagalna\%20serednya/nova-ukrainska-shkola-compressed.pdf [in Ukrainian].

9. Pro deiaki pytannia derzhavnykh standartiv povnoi zahalnoi serednoi osvity : Postanova Kab. Ministriv Ukrainy vid 30.09.2020 r. № 898 [On some issues of state standards of general secondary education: Resolution of the Cabinet. Ministers of Ukraine dated 30.09.2020 № 898]. (n.d.). www.kmu.gov.ua. Retrieved from https://www.kmu.gov.ua/npas/pro-deyaki-pitannyaderzhavnih-standartiv-povnoyi-zagalnoyi-serednoyi-osviti-i300920-898 [in Ukrainian].

10. Pro zatverdzhennia profesiinoho standartu za profesiiamy «Vchytel pochatkovykh klasiv zakladu zahalnoi serednoi osvity», «Vchytel zakladu zahalnoi serednoi osvity», «Vchytel z pochatkovoi osvity (z dyplomom molodshoho spetsialista)» : Nakaz vid 23.12.2020 r. № 2736-20 [On approval of the professional standard for the professions "Primary school teacher of general secondary education", "Teacher of general secondary education", "Primary teacher (with a diploma of junior specialist)": Order of 23.12.2020 № 2736-20]. (n.d.). zakon.rada.gov.ua. Retrieved from https://zakon.rada.gov.ua/rada/show/v2736915-20\#n10 [in Ukrainian].

11. Striletska N. M., \& Smahliuk O. S. (2020). Vykorystannia pryiomiv (tekhnik) formuvalnoho otsiniuvannia na urokakh informatyky u pochatkovii shkoli [The use of techniques (techniques) of formative assessment in computer science lessons in primary school]. Molodyi vchenyi - Young scientist, 6 (82), 355-363 [in Ukrainian].

12. Shcherbak, O. I., \& Sofii, N. Z., \& Bovych, B. Yu. (2014). Teoriia i praktyka otsiniuvannia navchalnykh dosiahnen [Theory and practice of assessment of academic achievement]. Ivano-Frankivsk: «Lileia-NV» [in Ukrainian]. 